\title{
SERO MONITORING OF ANTI RABIES VACCINAL ANTIBODIES TO PEP IN ANIMALS BY RFFIT - A CASE STUDY IN KARNATAKA
}

\section{Sunilkumar $\mathrm{KM}^{2}$, Isloor $\mathrm{S}^{1, *}$, Ansar Kamran $\mathrm{C}^{2}$, Santosh $\mathrm{AK}^{1}$, Ramesh $\mathrm{PT}^{2}$, Sharada $\mathrm{R}^{3}$, Yathiraj $\mathrm{S}^{2}$, Rathnamma $\mathrm{D}^{1}$, Suryanarayana $\mathrm{T}^{2}$, Patil $\mathrm{SS}^{4}$ and Abhinandan Patil ${ }^{4}$}

${ }^{1}$ KVAFSU-CVA-Crucell Rabies Diagnostic Laboratory, Dept. of Microbiology,

${ }^{2}$ Dept. of Medicine, Veterinary College, KVAFSU, Hebbal, Bengaluru-560024, Karnataka

${ }^{3}$ Dept. of Microbiology, Veterinary college, KVAFSU, Hassan, Karnataka

${ }^{4}$ Veterinary Hospital, Department of Animal Husbandry and Vety. Services, Govt. of Karnataka, Gangavathi-, Koppal, Karnataka

Received - August 25, 2016; Revision - October 14, 2016; Accepted - October 27, 2016

Available Online - October 30, 2016

DOI: 10.18006/2016.4(Spl-3-ADPCIAD).S103.S107

\section{KEYWORDS \\ Rabies \\ Post exposure prophylaxis \\ Neutralizing antibodies \\ Animals}

RFFIT

\begin{abstract}
A dog suspected to be affected with rabies attacked 31 animals in Kesarahatti village of Gangavathi taluk, Koppal District in Karnataka on $14^{\text {th }}$ June 2015. Of these, 26 animals (14 cattle, 5 buffaloes and 7 dogs) were given the first aid followed by post exposure anti rabies vaccine at 1 ( $15^{\text {th }}$ June 2015$), 3,7$, 14 and 28 days interval whereas the remaining 5 animals ( 2 cattle and 3 buffaloes) reportedly died of suspected (based on clinical manifestation) rabies after 8 days of dog bite episode. These 5 animals were not provided first aid and post exposure prophylactic (PEP) vaccination as their exposure to the rabid dog bite went unnoticed. Further, the serum samples could be collected from only 21 out of 26 vaccinated animals on $28^{\text {th }}$ and $90^{\text {th }}$ day post vaccination. These serum samples were tested by Rapid Fluorescent Focus Inhibition Test (RFFIT) and the titre of neutralizing antibodies ranged from 1-8 $\mathrm{IU} / \mathrm{ml}$ from the serum collected on $28^{\text {th }}$ day post vaccination indicating protection in all the vaccinated animals. But the titre ranged from 0.5-4 IU/ml in 18 animals and less than $0.5 \mathrm{IU} / \mathrm{ml}$ in three animals (2 cows and a dog) on $90^{\text {th }}$ day post vaccination. The protective level of neutralizing antibody titre on day 28 post vaccination and non-development of disease suggests that the PEP vaccination could be effective in livestock avoiding euthanasia and culling of animals.
\end{abstract}

* Corresponding author

E-mail: kisloor@gmail.com (Isloor S)

Peer review under responsibility of Journal of Experimental Biology and Agricultural Sciences.

Production and Hosting by Horizon Publisher India [HPI] (http://www.horizonpublisherindia.in/).

All rights reserved.
All the article published by Journal of Experimental Biology and Agricultural Sciences is licensed under a Creative Commons Attribution-NonCommercial 4.0 International License Based on a work at www.jebas.org.

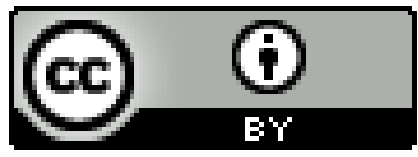




\section{Introduction}

Rabies is a viral zoonotic neuro invasive disease infecting all mammals and is usually fatal. In India, dogs are the major reservoirs of rabies virus and grazing livestock are commonly prone to rabid dog bites. The clinical manifestations are highly variable. The acute, maniacal, furious form is accompanied by hyperesthesia, bellowing, ataxia, charging of animate or inanimate objects, sexual excitement and rarely blindness and seizures (Lahunta, 1983). The paralytic form is rarely manifested in livestock.

The concept of post exposure therapy with tissue culture rabies vaccine is practiced in humans throughout the world. However, there are scanty reports on post exposure prophylactic vaccination trials in canines and other livestock including bovines (Basheer et al., 1997; Hanlon et al., 2002; James et al., 2007; Manickam et al., 2008). Post exposure treatment in animals is still controversial despite the fact that it has been practiced on large scale in certain situations in developed countries (Clark \& Wilson, 1996). The PEP treatment has been described for variety of species both experimentally and for field condition (Ramanna et al., 1991; Basheer et al., 1997). The data available regarding the efficacy of PEP and monitoring of anti-rabies vaccinal antibodies in domestic animals is scanty. Keeping this in view and frequent reports of rabies in cattle especially in the rural areas, in the present study, the PEP vaccination was evaluated by assessing anti rabies vaccinal neutralizing antibodies in different animal species using different vaccine brands.

\section{Materials and Methods}

\subsection{Animals}

A dog suspected to be affected with rabies attacked 31 animals in Kesarahatti village of Gangavathi taluk, Koppal District in Northern part of Karnataka on 14th June 2015. Of these, 26 animals (14 cattle, 5 buffaloes and 7 dogs) were seen being bitten by the rabies suspected dog whereas the remaining five animals ( 2 cattle and 3 buffaloes) were not seen being bitten by the suspected rabid dog. Hence only 26 animals were subjected to PEP vaccination. But, remaining five animals which were unvaccinated, died after 8 days of the incidence exhibiting symptoms suggestive of rabies. However, the post mortem brain sample of the rabies suspected dog or the five animals were not available for laboratory confirmation.

\subsection{Antirabies vaccination}

The twenty six animals bitten by the rabies suspected dog were subjected to the first aid followed by initiation of post exposure anti rabies vaccine at day 1(15th June 2015), 3, 7, 14 and 28 by intra muscular ( $\mathrm{I} / \mathrm{M})$ route. The Essen regime used for prophylaxis in humans was followed. Only 21 animals could be administered with the complete schedule of 5 shots since 5 animals were sold by the owners before the completion of the regimen. The vaccines used were BHK 21 cell culture inactivated vaccine "Raksharab", inactivated tissue culture vaccine "Anirab $\mathrm{H}$ " and inactivated vaccine containing Aluminium phosphate as an adjuvant "Nobivac R" used in dogs. All the animals were observed for 90 days after treatment for development of the clinical symptoms.

\subsection{Serum samples}

The blood samples were collected on $28^{\text {th }}$ day and $90^{\text {th }}$ day post vaccination from only 21 animals which received vaccine for the complete duration as the remaining 5 animals were sold and not traceable. The serum was separated in aseptic manner and stored at $-20^{\circ} \mathrm{C}$ until subjected for test.

\subsection{Rapid Fluorescent Focus Inhibition Test (RFFIT)}

The titration of rabies neutralizing antibodies was carried out using RFFIT a "gold standard" in-vitro test according to Smith et al., 1996 using the BHK 21 cell line. 100 TCID 50 of rabies virus PV 3462 (Dr. Larghi's strain) provided by Pasteur Institute, Coonoor, Tamil Nadu in 96 well microtitre plate. The WHO international standard for rabies Immunoglobulin (NIBSC, potters Bar, UK) was used as a positive control.

In brief, two fold serially diluted (1:2 to $1: 16)$ heat inactiviated test serum samples were mixed with 100 TCID ${ }_{50}$ Dr. Larghi's strain of rabies virus and incubated at $37{ }^{\circ} \mathrm{C}$ for 90 minutes with $5 \% \mathrm{CO}_{2}$ for neutralization. About $60 \mu 1$ of 3 to 4 days old BHK cells $(25,000$ to 30,000 cells/well) were added to all the wells. Standard WHO reference serum and negative serum was included in each test. A virus and cell controls were maintained. The microtitre plate was incubated at $37{ }^{\circ} \mathrm{C}$ in an atmosphere of $5 \% \mathrm{CO}_{2}$ for 48 hours. After incubation, the assay plate was observed under microscope for cell confluence.

The medium was decanted from the plate without disturbing the monolayer and $100 \mu 170 \%$ ice cold acetone was added and the plate incubated for 30 minutes at $-20^{\circ} \mathrm{C}$ and thereafter acetone was decanted and allowed the plate to dry. Further, $50 \mu 1$ of Rabies anti- nucleocapsid conjugate (Light Diagnostics, Rabies DFA III Cat \# 6500) at working dilution (1:100) was added to cover the entire monolayer and the plate incubated at $37{ }^{\circ} \mathrm{C}$ with $5 \% \mathrm{CO}_{2}$ for 45 minutes. After incubation, the plate was washed with sterile Phosphate Buffer Saline twice. The plate was observed under fluorescent microscope at $20 x$ objective. The antibody titers of serum were expressed in International Unit (IU) per milliliter (IU/mL) by comparing results obtained with those of the positive standard. A titre of minimum $0.5 \mathrm{IU} / \mathrm{ml}$ was considered protective as per WHO. 

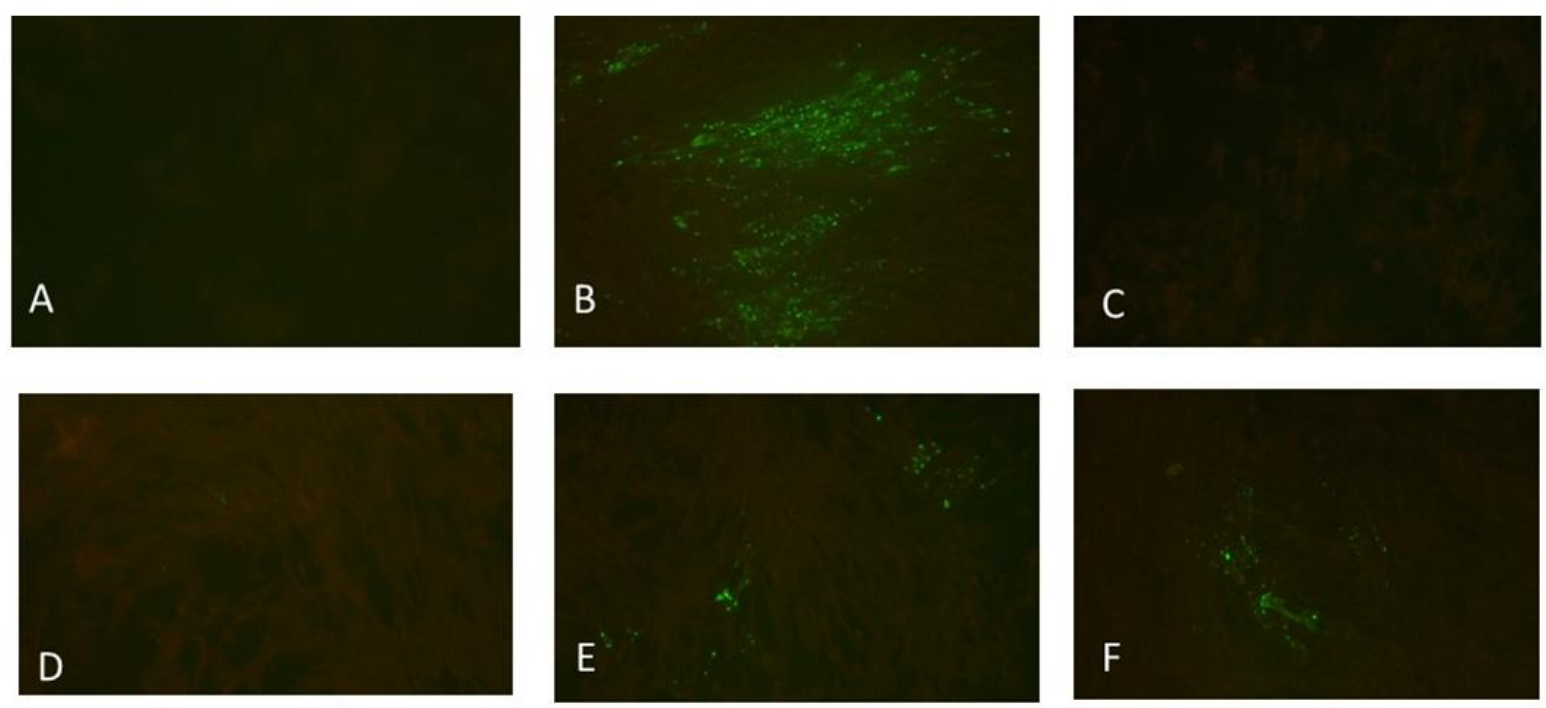

Figure 1 RIFFIT analysis in microscope at 100X magnification. A. Cell control; B : Virus control showing fluorescing foci.C: 1 in 2 dilution of serum sample ( $0.5 \mathrm{IU})$ without any fluorescing foci, D, E, and F are 1 in 4,8 and 16 dilution of serum sample (0.5 IU) showing fluorescing foci.

\section{Results and Discussion}

In this episode of a suspected rabid dog bite, all the animals which received PEP were under observation for 90 days. None of the animals showed clinical signs during the observation period although most of them had received a bite on their face. Five of the animals ( 2 cattle and 3 buffaloes) which had not received the PEP died after 8 days of dog bite, exhibiting symptoms suggestive of rabies. According to Starr (2001), there is a latent period of three to four days before multiplication and attachment to nerve endings occur. Whether there is a short or long incubation period depends on a number of factors: the length of temporary arrest of virus multiplication, either at the site of deposition or at some location in the nerve system; the number of viral particles deposited in the tissues, and the virulence of the particular strain of virus. The street virus rabies is characterised by a variable incubation period. In the present study, RFFIT was employed to estimate the anti-rabies neutralizing vaccinal antibody titres and a minimum of 0.5 iu was considered protective (Figure 1). All the post vaccinal sera collected showed antibody titer on day 28 and lower titers at three months. Further, all the three vaccine brands used by employing the Essen regime were found to be protective in all the vaccinated animals similar to the observation of Basheer et al. (1997). A titre of $>0.5 \mathrm{IU}$ (1-8 IU) was evident in case of all the vaccinated animals on the $28^{\text {th }} \mathrm{dpv}$. However, the neutralizing anitbody response was seen to be protective (in the range of $0.5-4 \mathrm{IU}$ ) in case of 18 animals and was $<5 \mathrm{IU}$ in the remaining 3 animals on the $90^{\text {th }} \mathrm{dpv}$ (Table1).

This finding indicated the elevation of antibody response on day $28^{\text {th }}$ and waning of the same on the day $90^{\text {th }}$. Similar observations of peak antibody titre during 3-6 weeks post vaccination and waning of antibody titre were made earlier (Aubert, 1992; Oliveira et al., 2000; Manickam et al., 2008; Minke et al., 2009). Although reduction in the antibody response on the day 90 was expected, it's reduction below 0.5 IU in case of 3 animals was unexpected. Although various factors including the breed, size, age, maintenance of cold chain, regimen employed could influence the titre, in this study it is difficult to attribute any specific reason to explain such reduction in the titre $<0.5 \mathrm{IU}$.

Nevertheless, the initial elevation of antibody response $>0.5$ IU in case of all the vaccinated animals is important to neutralize the virus as observed. Some studies conducted earlier (Cho \& Lawson, 1989; Clark \& Wilson, 1996) included a booster vaccination on the day 90 . However, the study supports the findings of Shayam et al. (2006), Hoque et al. (2006) and Wilson \& Clark (2001) revealing a protective titer after 5 vaccinations i.e., day $0,3,7,14$ and 28 days. Although on 90 $\mathrm{dpv}$, the virus neutralizing titers irrespective of the vaccine used appeared to be waning, it is likely that the immunity thus stimulated would last for a much longer period. Manickam et al. (2008) challenged dogs intramuscularly with virulent rabies virus brain suspension and injected intramuscularly with either Nobivac Rabies (Intervet), Rabisin (Merial) or placebo on multiple occasions ( 3 or 5 -times) over the next 28 days. They recorded the serum antibody production after 3 days of post vaccination with maximum antibody titre seen on 28th dpv in dogs. In their study, the neutralizing antibodies had declined by day 90. They also compared response of antibody production using 2 different cell culture rabies vaccines in Indian street dogs and concluded that both vaccines were found to be safe and effective similar to the observations of our study. 
Table 1 Details of neutralizing antibody response in vaccinated cattle, Buffaloes and Dogs.

\begin{tabular}{|c|c|c|c|c|c|c|c|}
\hline $\begin{array}{l}\text { Sl. } \\
\text { No. }\end{array}$ & Animal & Age & Sex & Vaccine used & $\begin{array}{c}\text { Place of } \\
\text { bite }\end{array}$ & $\begin{array}{l}\text { Antibody titer of } \\
\text { samples collected } \\
\text { on day } 28(\mathrm{IU})\end{array}$ & $\begin{array}{c}\text { Antibody titer of } \\
\text { samples collected } \\
\text { on day } 90 \text { (IU) }\end{array}$ \\
\hline 1 & Cow (HF CB ) & 6 Month & Male & Raksharab & Face & 8 & 1 \\
\hline 2 & Cow (HF CB ) & $5 \mathrm{yr}$ & Female & Anirab & Leg & 1 & 1 \\
\hline 3 & Cow (HF CB ) & 8 month & Female & Raksharab & Nose & 8 & 2 \\
\hline 4 & Cow (HF CB ) & 6 month & Female & Raksharab & Face & 4 & $<0.5$ \\
\hline 5 & Cow (HF CB ) & $6 \mathrm{yr}$ & Female & Raksharab & & 1 & 2 \\
\hline 6 & Cow (JR CB) & $6 \mathrm{yr}$ & Female & Raksharab & & 2 & 4 \\
\hline 7 & Cow (HF CB ) & 6 month & Female & Raksharab & & 4 & $<0.5$ \\
\hline 8 & Cow (HF CB ) & $6 \mathrm{yr}$ & Female & Raksharab & & 2 & 4 \\
\hline 9 & Bullock & $6 \mathrm{yr}$ & Male & Anirab & Face & 1 & 0.5 \\
\hline 10 & J Cow (JR CB) & $7 \mathrm{yr}$ & Female & Raksharab & Face & 2 & 0.5 \\
\hline 11 & Cow (JR CB) & $6 \mathrm{yr}$ & Female & Raksharab & Face & 1 & 4 \\
\hline 12 & Cow (local) & $5 \mathrm{yr}$ & Female & Raksharab & Leg & 1 & 2 \\
\hline 13 & Buffalo & 8 month & Male & Raksharab & Face & 4 & 1 \\
\hline 14 & Buffalo & $6 \mathrm{yr}$ & Female & Raksharab & $\begin{array}{l}\text { Nostrils, } \\
\text { eye and } \\
\text { head }\end{array}$ & 1 & 2 \\
\hline 15 & Buffalo & 6 month & Female & Raksharab & & 4 & 2 \\
\hline 16 & Buffalo & 6 month & Female & Raksharab & Face & 2 & 2 \\
\hline 17 & Dog (GSD) & 9 month & Male & Raksharab & Legs & 2 & 4 \\
\hline 18 & Dog (Street) & - & - & Anirab & Face & 2 & $<0.5$ \\
\hline 19 & Dog (Street) & - & Male & Anirab & & 4 & 4 \\
\hline 20 & Dog (Street) & - & Male & Raksharab & & 2 & 2 \\
\hline 21 & Dog (Dachshund) & $1.5 \mathrm{yr}$ & Male & Nobivac $\mathrm{R}$ & Face & 4 & 2 \\
\hline
\end{tabular}

\section{Conclusion}

In conclusion, the PEP could be effective in livestock, although there was reduction in the neutralizing antibody titre below protective level of $0.5 \mathrm{IU}$ in 3 out of 21 vaccinated animals at the end of $90 \mathrm{dpv}$, probably the elevation of antibody level above the protective level on day $28^{\text {th }} \mathrm{dpv}$ must have conferred protection. Despite these encouraging observations, the present limited field based study may not necessarily suggest the replacement of quarantine by PEP unless more such field based investigations are done especially with a view to ensure the elevated antibody response (>0.5 IU) beyond 90 days.

Furthermore, simultaneous administration of rabies immunoglobulin (RIG) at the local site of bite (subject to cost effectiveness) in case of category 3 bites along with PEP vaccination shall be explored in animals as is being done in human beings. Such data could enable undertaking routine PEP vaccination in livestock exposed to rabies and thereby avoid euthanasia or prolonged quarantine.

\section{Conflict of interest}

Authors would hereby like to declare that there is no conflict of interests that could possibly arise.

\section{References}

Aubert MF (1992) Practical significance of rabies antibodies in cats and dogs. Revue Scientifique et Technique 11:735-60.

Basheer AM, Ramakrishna J, Manickam R (1997) Evaluation of post exposure vaccination against rabies in cattle. Microbiologica 20:289-294.

Cho HC, Lawson KP (1989) Protection of dogs from experimental rabies by post exposure administration of rabies vaccine and hyperimmune globulin (human). Canadian Journal of Veterinary Research 53:434-437.

Clark KA, Wilson PJ (1996) Post exposure scheme prophylaxis and pre-exposure vaccination failure in domestic animals. The Journal of the American Medical Association 208:827-1830.

Hoque M, Islam T, Das DSC, Jabeen N, Islam T (2006) An overview of rabies in man and animals. Intas polivet 7:388-98.

Hanlon CA, Niezgoda M, Rupprecht CE (2002) Post-exposure prophylaxis for prevention of rabies in dog. American Journal of Veterinary Research 63:1096-1100. 
James R, Saseendranath MR, Vijayakumar K (2007) Immune response between two anti-rabies vaccines in two different schedules in rabies exposed goats. The Indian veterinary journal 84:1128-1130.

Lahunta AD (1983) Veterinary Neuroantonomy and Clinical Neurology. Saunders

Manickam R, Basheer MD, Jayakumar R (2008) Post-exposure prophylaxis (PEP) of rabies-infected Indian street dogs. Vaccine 26:6564-6568. doi: 10.1016/j.vaccine.2008.09.053.

Minke JM, Bouvet J, Cliquet F, Wasniewski M, Guiot AL, Lemaitre L, Cariou C, Cozette V, Vergne L, Guigal PM (2009) Comparison of antibody responsesafter vaccination with two inactivated rabies vaccines. Veterinary Microbiology 133:283-286. http://dx.doi.org/10.1016/j.vetmic.2008.06.024.

Oliveira AN, Andrade MCR, Silva MV, Moura WC, Contreras EC, (2000) Immune response in cattle vaccinated against rabies. Memórias do Instituto Oswaldo Cruz 95: 83-88. DOI: http://dx.doi.org/10.1590/S0074-02762000000100013.

Ramanna BC, Reddy GS, Srinivassan VA (1991) An outbreak of rabies in cattle and use of tissue culture rabies vaccine during the outbreak. Journal of Communicable Diseases 23:283-285.

Shayam C, Duggal AK, Kamle U, Agarwal AK (2006) Postexposure prophylaxis for rabies. Journal, Indian Academy of Clinical Medicine 7:39-46.

Starr LE (2001) Viral disease. In: Fincher MG, Gibbons WJ, Mayer K, Park SE (Eds.) Diseases of cattle, A Text and reference work. Green world publishers.

Wilson PJ, Clark KA (2001) Post-exposure rabies prophylaxis protocol for domestic animals and epidemiologic characteristics of vaccination failure in Texas: 1995-1999. Journal of the American Veterinary Medical Association 218:522-525 